\title{
Removal of chromium from synthetic wastewater by adsorption onto Ethiopian low-cost Odaracha adsorbent
}

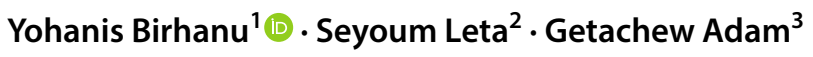

Received: 24 February 2020 / Accepted: 2 October 2020 / Published online: 16 October 2020

(c) The Author(s) 2020

\begin{abstract}
Nowadays, Cr-loaded wastewater released from industrial activities pose an increasing risk to human health and the environment. Adsorption processes have been widely used for the removal of chromium from the waste stream. In this regard, natural adsorbents are the most preferable and cost-effective methods. In this study, the efficiency of Odaracha adsorbent as a novel green technology in the removal of chromium from synthetic wastewater is analyzed. Batch adsorption experiments were conducted to evaluate the effect of contact time, $\mathrm{pH}$, adsorbent dose, and initial concentration of adsorbate on $\mathrm{Cr}$ removal. The surface morphology of Odaracha adsorbent was characterized by scanning electron microscopy, Fourier transform infrared spectroscopy, and X-ray powder diffraction. Experimental results showed that Odaracha adsorbent could perform effectively in a wide range of experimental conditions. However, in optimum experimental conditions, such as $180-$ min contact time, $\mathrm{pH} 3$, and $15 \mathrm{~g} / \mathrm{L}$ of adsorbent dose Odaracha adsorbent removes $94.68 \%$ of $\mathrm{Cr}$ from an aqueous solution having $110 \mathrm{mg} / \mathrm{L}$ of $\mathrm{Cr}$ concentration.
\end{abstract}

Keywords Odaracha $\cdot$ Synthetic wastewater $\cdot$ Chromium $\cdot$ Adsorption

\section{Introduction}

Metals are ubiquitous in the environment because of their wide application (Ajmani et al. 2019b). They are present in the solid phase and solution, as free ions, or adsorbed to colloidal soil particles. From these metals, hexavalent chromium has no known vital or beneficial effect on organisms, even for bacterial cells, and its accumulation over time in organisms can cause serious illness even at low concentration. According to World Health Organization (WHO) guidelines, the allowable concentration of $\mathrm{Cr}$ (VI) in drinking water is $50 \mathrm{ppb}$ (Jiang et al. 2013). However, humans could be exposed to higher-level chromium

Yohanis Birhanu

yohanis.birhanu@aau.edu.et

1 Department of Chemistry, College of Natural and Computational Science, Jigjiga University, P.O. Box 1020, Jigjiga, Ethiopia

2 Center of Environmental Science, Addis Ababa University, P.O. Box 1176, Addis Ababa, Ethiopia

3 Department of Industrial Chemistry, Center of Excellence in Sustainable Energy, Addis Ababa Science and Technology University, P.O. Box 16417, Addis Ababa, Ethiopia contamination through food or drinking water. Industries such as leather tanning, steel fabrication, metal finishing, and other industrial sources related to wood preservation are the major causes of this contamination (Eliku and Leta 2018). The human health effects of hexavalent chromium exposure are respiratory irritation, dermatitis, lung cancer, kidney, and liver damage (Ofudje et al. 2014; Jiang et al. 2013). Therefore, the removal of $\mathrm{Cr}$ would be necessary to improve the quality of water and the life of humanity. In line with minimizing the adverse effect on human health nowadays, there are several $\mathrm{Cr}$ removal mechanisms. For the removal of chromium from wastewater, adsorption is highly effective compared to other conventional methods (Pranay et al. 2015; Shahnaz et al. 2020b). Adsorption is a process that occurs when a gas or liquid or solute (called adsorbate) accumulates on the surface of a solid or more rarely a liquid (adsorbent), forming a molecular or atomic film. Adsorption process can be influenced by a number of factors such as $\mathrm{pH}$, adsorbate concentration, adsorbent dosage, and other factors (Costanzo et al. 2012).

Most clay can soak up electrically charged atoms and molecules from the solution. Clays' mineral composition, crystal structural characteristics, and their crystalline size make them potentially sound absorbers (Hoidy et al. 2009). 
Besides, because of their availability and cost-effectiveness, clay minerals become the most critical industrial resource. As a result, clays have received considerable attention, especially as potential adsorbents for environmental research. In line with the adsorption potential of clay mineral, in the eastern part of Ethiopia, specifically in Saketa district, there is a clay locally named Odaracha. In most of the rural areas of West Hararghe zone of Oromia, regional state peoples depend on this particular kind of clay (Odaracha clay) to remove turbidity of water in their day-to-day life and commercially exchanged in the market for this particular purpose in some woredas. Odaracha soil is a novel adsorbent material and has not been reported in the literature. Therefore, the principal aim of this study was to investigate the effectiveness of Odaracha clay in the removal of $\mathrm{Cr}$ from synthetic wastewater. The effect of various parameters such as contact time, $\mathrm{pH}$, adsorbent dose, and initial concentration of adsorbate on adsorption efficiency of Odaracha was considered.

\section{Materials and methods}

\section{Chemicals and analytical methods}

The chemicals consumed in these set of experimental activities were all of analytical grade. The standard stock solution of chromium $(1000 \mathrm{mg} / \mathrm{L})$ was prepared by dissolving $2.828 \mathrm{~g}$ of $99.9 \%$ analytical-grade $\mathrm{K}_{2} \mathrm{Cr}_{2} \mathrm{O}_{7}$ in $1000 \mathrm{~mL}$ of distilled water. All the required solutions are made ready with analytical-grade reagents and double-distilled water. Synthetic samples of different concentrations of chromium are prepared from this stock solution by appropriate dilutions. The functional groups involved in the adsorption process were identified by Fourier transform infrared (FTIR) spectroscopy (Model 65 spectrometer, USA). X-ray powder diffraction analysis was performed using the XRD spectrometer (PAN analytical X'Pert Pro) with recorded $2 \theta$ XRD patterns of $5^{\circ}$ to $60^{\circ}$. The surface morphology of Odaracha adsorbent was characterized using INSPECT F50 field emission scanning electron microscope (SEM).

\section{Adsorbent preparation}

In this study, a locally available soil type, known by the local community as Odaracha clay, was used as an adsorbent. This natural coagulant is abundantly available in Saketa District West Hararghe zone of Oromia Regional State, Ethiopia. It is also commercially exchanged in the market of Boke Tiko woreda, and the rural communities have been using this clay material to remove water turbidity. In this research, the soil sample was taken from Saketa district (N: 08 ${ }^{\circ} 44^{\prime} 41.3^{\prime \prime}$ E: $040^{\circ} 45^{\prime} 15.1^{\prime \prime}$, altitude 1470). After air-dried, the soil has been crushed into the desired size and sieved using $125-\mu \mathrm{m}$ laboratory sieve. Finally, Odaracha powder was dried in the oven with a $120{ }^{\circ} \mathrm{C}$ temperature level for $6 \mathrm{~h}$ and kept inside the desiccator until the adsorption experiment.

\section{Batch adsorption experiments}

The batch adsorption studies were conducted at room temperature by agitating measured quantities of the Odaracha adsorbent in $50 \mathrm{ml}$ of synthetic wastewater at the rate of $150 \mathrm{rpm}$ with the required $\mathrm{pH}$, contact time, dose of the adsorbent and initial concentration of the adsorbate. The timing was started upon the addition of adsorbent. These experiments were run in different Erlenmeyer flasks having a capacity of $150 \mathrm{ml}$. After shaking, the sample was taken and filtered by the Whatman membrane filter paper of pore size $0.45 \mu \mathrm{m}$. Finally, the sample was analyzed by FAAS (Flame Atomic Absorption Spectrophotometer, Model 210 VGP) for the remaining chromium ion in the solution. The experiments were undertaken in triplicate, and the average results are presented. The removal efficiencies of Odaracha adsorbent were investigated based on the following equations. The percentage of chromium removal is obtained using Eq. 1, while the adsorption capacity $q_{e}$ is calculated using Eq. 2 .

\%removal $=\frac{\left(C_{\mathrm{o}}-C_{\mathrm{e}}\right)}{C_{\mathrm{o}}} \times 100$

where $C_{\mathrm{o}}=$ initial adsorbate concentration $(\mathrm{mg} / \mathrm{L}) ; C_{\mathrm{e}}=$ final equilibrium adsorbate concentration $(\mathrm{mg} / \mathrm{L})$.

$q_{e}=\frac{\left(C_{\mathrm{o}}-C_{\mathrm{e}}\right) V}{w}$

where $C_{\mathrm{o}}$ and $C_{\mathrm{e}}$ are the initial and equilibrium liquid-phase concentrations of the $\mathrm{Cr}$ ions in $\mathrm{mgL}^{-1}$, respectively, $V$ is the volume of the solution in $\mathrm{L}, w$ is the amount of adsorbent used in $\mathrm{g}$, and $q_{\mathrm{e}}$ is the removal efficiency of adsorbent in $\mathrm{mg} / \mathrm{g}$.

\section{Isotherm and kinetic studies}

To study the adsorption isotherms, the optimum conditions found in optimization experiments were applied only by varying adsorbent doses. These experiments were carried out using adsorbent dose in the range of $1,3,5,7,10,15$, and $20 \mathrm{~g} / \mathrm{L}$. For each adsorbent dosage, $50 \mathrm{ml}$ of the sample was taken and agitated at $150 \mathrm{rpm}$. The data from the experiment were fitted into Langmuir and Freundlich adsorption isotherm models (Gulipalli et al. 2011). It is essential to know the rate at which the process takes place, factors that control the rate of the process; for this reason, the kinetics of the processes were assessed. These experiments were 
conducted by setting heavy metal concentration, $\mathrm{pH}$, adsorbent dosage, and agitation speed constant. Then, the sample was withdrawn at $30,60,90,120,150,180$, and $210 \mathrm{~min}$ for the determination of residual heavy metals in the solution. Then, data from the experiment were introduced into the pseudo-first-order model of Lagergren and pseudo-secondorder models of Ho and McKey (Dagmawi and Mekibib 2013; Gulipalli et al. 2011).

\section{Results and discussion}

\section{Characterization of Odaracha adsorbent}

\section{Scanning electron microscope (SEM) studies}

The scanning electron microscope (SEM) images shown in Fig. 1 revealed the surface morphology of Odaracha adsorbent before and after adsorption. As shown in Fig. 1a, $\mathrm{b}$ Odaracha adsorbent appears rough and porous before adsorption. However, as depicted in Fig. 1c, d, the morphology of Odaracha adsorbent after $\mathrm{Cr}$ adsorption appears different where the pores are filled and much smoother. This is an indication of the adsorption of $\mathrm{Cr}$ onto the surface of Odaracha adsorbent.

\section{FTIR studies}

The FTIR spectra of Odaracha clay are shown in Fig. 2. The spectra in the region $3200-3650 \mathrm{~cm}^{-1}$ and the maximum peak $3408 \mathrm{~cm}^{-1}$ were due to $-\mathrm{OH}$ stretching vibration. The strong peaks at 2519, 1432, and $1038 \mathrm{~cm}^{-1}$ were due to $\mathrm{O}-\mathrm{H}$ (carboxylic acid) stretching, $\mathrm{C}-\mathrm{O}$, and $\mathrm{Si}-\mathrm{O}-\mathrm{Si}$ (organic siloxane or silicone) bond, respectively (Ghoneim et al. 2014; Kyziol-Komosinska et al. 2014). The spectra viewed below $1000 \mathrm{~cm}^{-1}$ are more comparable to the mineral features of the material. To identify the possible functional groups on Odaracha adsorbent involved in the binding of Cr, FTIR spectra were obtained before and after adsorption. If a ligand coordinates to a metal, the ligand material's energy will most likely be disturbed, leading ultimately to shifts in the absorption peaks in the FTIR spectra. These FTIR adsorption bands are ordinarily shifted to lower or upper frequencies. In this regard, there are small shifts of vibration from 873, 1038, 2131, 2519, 2874 , and $3408 \mathrm{~cm}^{-1}$ in Odaracha adsorbent to 872,1027 , $2127,2518,2870,3408 \mathrm{~cm}^{-1}$ for chromium-loaded adsorbent, respectively. The disappearance of intensities and shifting of peaks to new values signify the involvement of functional groups in the adsorption process.
Fig. 1 SEM images of Odaracha adsorbent before adsorption (a, b) and after adsorption (c, d)
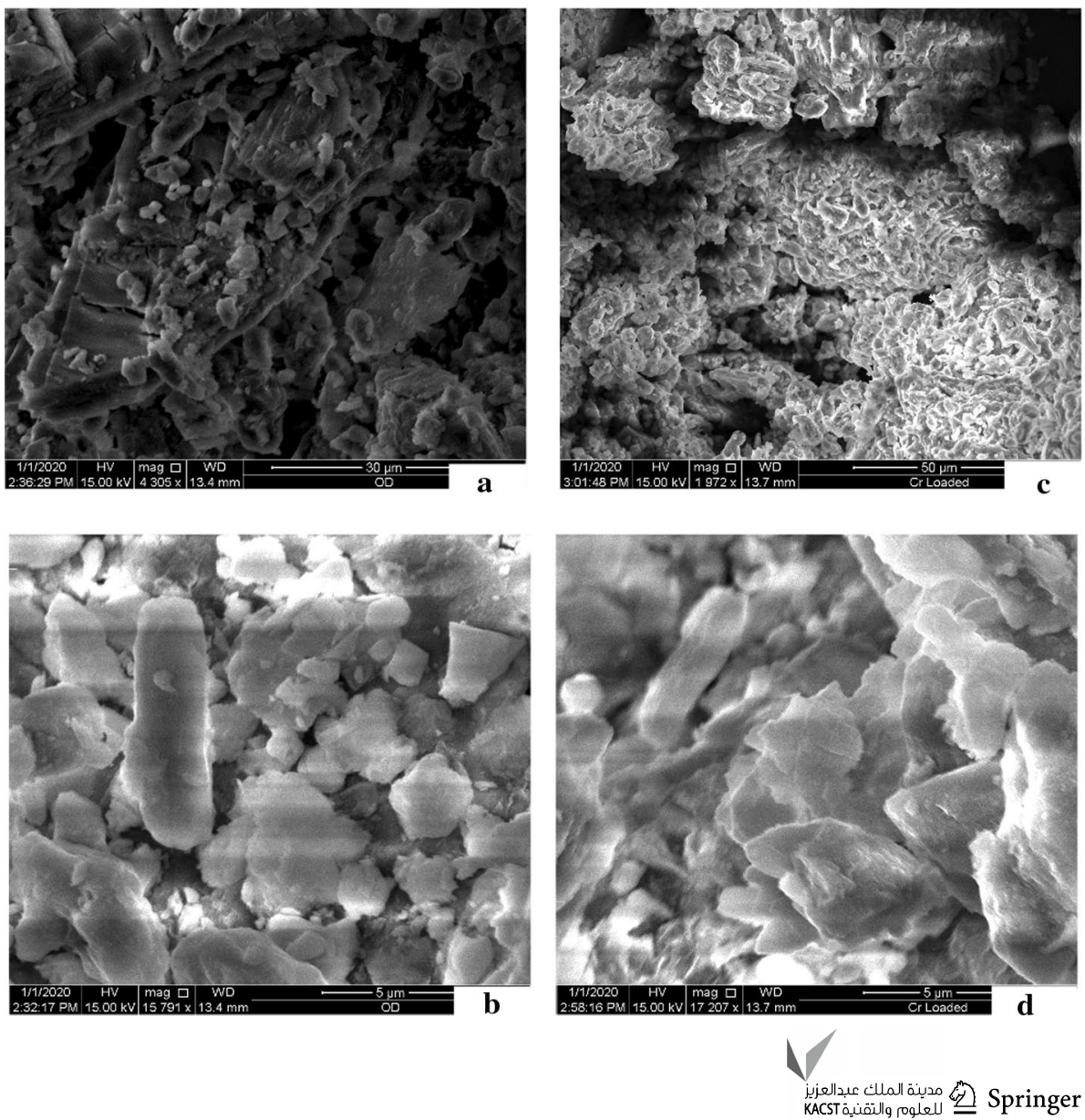

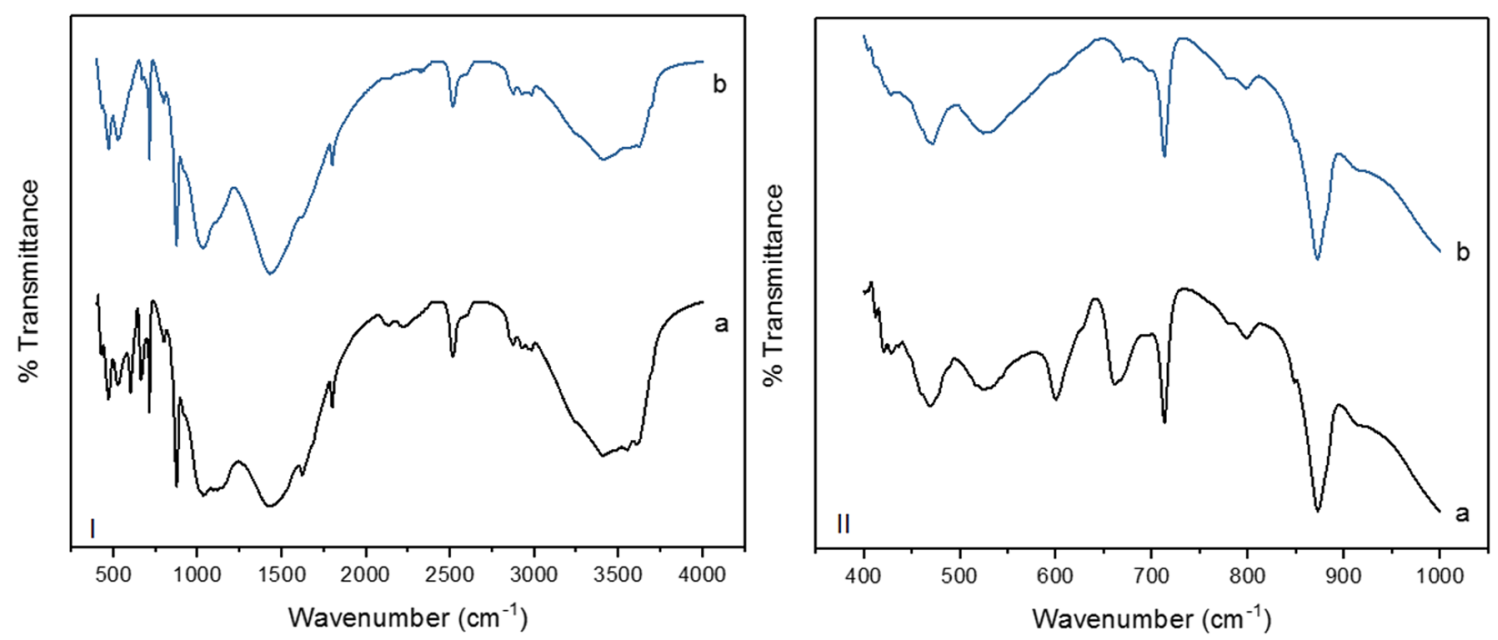

Fig. 2 FTIR spectrum (400-4000 $\mathrm{cm}^{-1}$ (I) and 400-1000 $\mathrm{cm}^{-1}$ (II)) of raw (a) and chrome-loaded (b) Odaracha powder

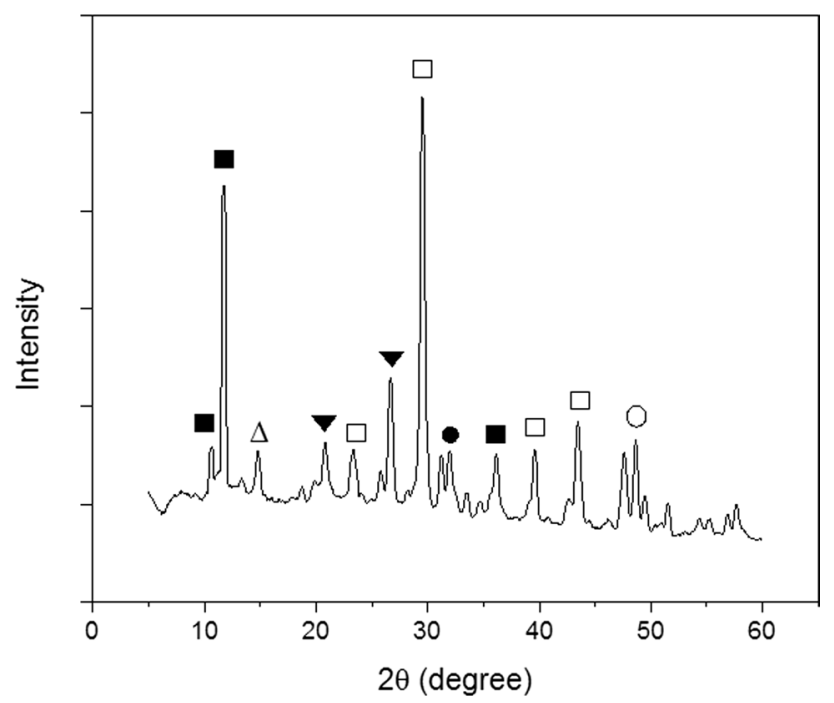

Fig. 3 X-ray diffraction patterns of raw Odaracha clay. Mineral assignments: gypsum ( $\mathbf{\square})$, alumina $(\Delta)$, quartz ( $\mathbf{\nabla})$, calcite ( $\square$ ), dolomite $(\bigcirc)$ and magnetite $(\bigcirc)$

\section{XRD studies}

X-ray diffraction (XRD) analysis was commenced using $\mathrm{Cu} \mathrm{K} \alpha 1$ radiation on a computer-controlled XRD machine model of $X^{\prime}$ pert pro-PANalytical. XRD patterns were recorded from $5^{\circ}$ to $60^{\circ} 2 \theta$. The XRD peaks and analysis for raw Odaracha clay before adsorption are shown in Fig. 3. The XRD analysis of powder Odaracha clay revealed the presence of gypsum, alumina, quartz, calcite, dolomite, and magnetite. The characteristic peaks at 23.34, 29.5, 39.6 , and 43.36 for the raw Odaracha sample indicated calcite $\left(\mathrm{CaCO}_{3}\right)$ as the main constituent. Some characteristic peaks at $10.62,11.74$, and 36.1 show the presence of gypsum $\left(\mathrm{CaSO}_{4} \cdot 2 \mathrm{H}_{2} \mathrm{O}\right)$; the peaks at 20.82 and 26.64 show the
Table 1 Effect of contact time on $\mathrm{Cr}$ removal efficiency $\left(\mathrm{C}_{\mathrm{o}}=110 \mathrm{mg} / \mathrm{L}\right.$, agitation speed $\left.=150 \mathrm{rpm}\right)$

\begin{tabular}{lllrll}
\hline $\begin{array}{l}\text { Contact } \\
\text { time } \\
(\mathrm{min})\end{array}$ & $\mathrm{pH}$ & $\begin{array}{l}\text { Dose } \\
(\mathrm{g} / \mathrm{L})\end{array}$ & \multicolumn{1}{c}{$\mathrm{C}_{\mathrm{f}}(\mathrm{mg} / \mathrm{L})$} & $\begin{array}{l}\mathrm{Cr} \\
\text { adsorp- } \\
\text { tion \% }\end{array}$ & $\mathrm{q}\left(\mathrm{mg} \mathrm{g}^{-1}\right)$ \\
\hline 60 & 3 & 15 & $32.792 \pm 0.095$ & 70.189 & 5.147 \\
120 & 3 & 15 & $26.500 \pm 0.063$ & 75.909 & 5.567 \\
180 & 3 & 15 & $5.854 \pm 0.130$ & 94.678 & 6.943 \\
240 & 3 & 15 & $6.896 \pm 0.072$ & 93.731 & 6.874 \\
\hline
\end{tabular}

presence of quartz $\left(\mathrm{SiO}_{2}\right)$; the peak at 14.6 shows the presence of alumina $\left(\mathrm{Al}_{2} \mathrm{O}_{3}\right)$; the peaks at 32 and 48.64 show the presence of dolomite $\left(\mathrm{CaMg}\left(\mathrm{CO}_{3}\right)_{2}\right)$ and magnetite $\left(\mathrm{Fe}_{3} \mathrm{O}_{4}\right)$, respectively.

\section{Effect of various parameters on adsorption of chromium}

\section{Effect of contact time}

Effect of contact time between the adsorbate and adsorbent particles is one of the important factors in the adsorption studies. To realize the effect of contact time on $\mathrm{Cr}$ adsorption on Odaracha adsorbent and to discern the optimum contact time between the adsorbate and adsorbent, the experiment was carried out at room temperature and led within the time range of 60-240 min in 60-min interval using $15 \mathrm{~g} / \mathrm{L}$ adsorbent dose and by tuning $\mathrm{pH}$ of the solution at 3 . Other parameters such as agitation speed and adsorbate concentration were retained constant to $150 \mathrm{rpm}$ and $110 \mathrm{mg} / \mathrm{L}$, respectively.

The result of the effect of contact time revealed in Table 1 shows that with an increase in contact time there is also an increase in percent adsorption of $\mathrm{Cr}$. There was very rapid 
adsorption at the initial period up to $60 \mathrm{~min}$, and after that, the increase in the adsorption rate was gradual. The adsorption process attained equilibrium in $180 \mathrm{~min}$, which was 94.68\%. Then, no significant change in $\mathrm{Cr}$ removal was observed after $180 \mathrm{~min}$. This is attributed to a large number of vacant surface sites which are available for adsorption during the initial stage of adsorption. As it is shown in Table 1, percentage of removal efficiency of chromium and adsorption of chromium in $\mathrm{mg} / \mathrm{g}$ showed the same type of increasing trend since there was no variation of adsorbent dose in this set of experiments.

\section{Effect of $\mathrm{pH}$}

The $\mathrm{pH}$ is a principal parameter in adsorption process because of its effect on the adsorption efficiency (Attia et al. 2010; Shahnaz et al. 2020a). The functional groups responsible for the binding of metal ions in the adsorbent surface are profoundly affected by $\mathrm{pH}$. There is also a competition between ions that are present in the solution for the adsorbent's active sites. This competition is affected by the $\mathrm{pH}$ of the solution (Reddy et al. 2014). The effect of $\mathrm{pH}$ on the adsorption process was examined by undertaking the batch procedure at 120-min contact time, under room temperature, constant agitation speed which is $150 \mathrm{rpm}$, and $15 \mathrm{~g} / \mathrm{L}$ of adsorbent dosage. The investigation results on the effect of $\mathrm{pH}$ on chromium removal by Odaracha adsorbent are revealed in Table 2. As illustrated in Table 2, it was found that the uptake of $\mathrm{Cr}$ increases with decreasing $\mathrm{pH}$. Accordingly, the optimum $\mathrm{pH}$ for the maximum uptake of chromium was $\mathrm{pH}$ 3. In this regard, Odaracha adsorbent gave the highest removal percentage at $\mathrm{pH} 3$, which is $76.31 \%$.

Conversely, the minimum adsorption capacity was observed at $\mathrm{pH} 6$, which is $74.15 \%$. In this experimental condition, since the adsorbent dose and initial concentration of the adsorbate had been kept constant, both adsorption percent and removal in $\mathrm{mg} / \mathrm{g}$ show similar increasing trends with decreasing $\mathrm{pH}$ of the solution (Ajmani et al. 2019b). As per the result, the maximum chromium uptake in $\mathrm{mg} / \mathrm{g}$ was detected at $\mathrm{pH} \mathrm{3,} \mathrm{which} \mathrm{is} 5.596 \mathrm{mg} / \mathrm{g}$. At acidic $\mathrm{pH}$, the dominant form of hexavalent chromium is $\mathrm{HCrO}_{4}^{-}$, and at higher $\mathrm{pH}$, other forms $\mathrm{CrO}_{4}{ }^{2-}$ or $\mathrm{Cr}_{2} \mathrm{O}_{7}{ }^{2-}$ predominate.

Table 2 Effect of $\mathrm{pH}$ on $\mathrm{Cr}$ removal efficiency $\left(C_{\mathrm{o}}=110 \mathrm{mg} / \mathrm{L}\right.$, agitation speed $=150 \mathrm{rpm}$ )

\begin{tabular}{llllll}
\hline $\mathrm{pH}$ & $\begin{array}{l}\text { Contact } \\
\text { time } \\
(\mathrm{min})\end{array}$ & Dose $(\mathrm{g} / \mathrm{L})$ & $C_{f}(\mathrm{mg} / \mathrm{L})$ & $\begin{array}{l}\text { Cr adsorp- } \\
\text { tion } \%\end{array}$ & $\mathrm{q}\left(\mathrm{mg} \mathrm{g}^{-1}\right)$ \\
\hline 3 & 120 & 15 & $26.063 \pm 0.125$ & 76.307 & 5.596 \\
4 & 120 & 15 & $26.500 \pm 0.063$ & 75.909 & 5.567 \\
5 & 120 & 15 & $28.375 \pm 0.062$ & 74.205 & 5.442 \\
6 & 120 & 15 & $28.438 \pm 0.625$ & 74.148 & 5.438 \\
\hline
\end{tabular}

Therefore, the higher adsorption capacity observed at lower $\mathrm{pH}$ is due to the strong electrostatic attraction between surface groups and $\mathrm{HCrO}_{4}^{-}$(Singha and Das 2011; Zhu and Han 2013).

The interaction between $\mathrm{HCrO}_{4}^{-}, \mathrm{CrO}_{4}{ }^{2-}$ and $\mathrm{Cr}_{2} \mathrm{O}_{7}{ }^{2-}$ ion and adsorbent surface decreases at higher $\mathrm{pH}$ because the adsorbent surface becomes negatively charged, and also there is an abundance of $\mathrm{OH}^{-}$in aqueous solution, which can be attributed to the competitive adsorption of $\mathrm{Cr}_{2} \mathrm{O}_{7}{ }^{2-}$ and $\mathrm{OH}^{-}$. Other previous studies have also reported similar situations (Hsua et al. 2009; Owlad et al. 2010; Rangabhashiyam and Selvaraju 2015). In another way, at lower $\mathrm{pH}$, the degree of surface protonation is high, so that the surface offers a maximum positive charge for adsorption of $\mathrm{HCrO}_{4}{ }^{-}$, which is predominant at lower $\mathrm{pH}$. Therefore, at lower $\mathrm{pH}$, the predominant hydrogen chromate ion $\left(\mathrm{HCrO}_{4}{ }^{-}\right)$ requires one exchange site from Odaracha adsorbent to be adsorbed, while at higher $\mathrm{pH}$, it requires two exchange sites from Odaracha adsorbent for one chromate ion $\left(\mathrm{CrO}_{4}{ }^{2-}\right)$ adsorption (Nizam Nik Malek 2007). Generally, adsorption of chromium is higher in acidic media because at lower $\mathrm{pH}$, the degree of surface protonation is very high, which plays a vital role in capturing hydrogen chromate ion $\left(\mathrm{HCrO}_{4}{ }^{-}\right)$ in the solution.

\section{Effect of adsorbent dose}

As pointed out in Table 3, the effect of the dosage of Odaracha adsorbent on the removal efficiency of chromium was determined with varied adsorbent doses, which are $1 \mathrm{~g} / \mathrm{L}$, $5 \mathrm{~g} / \mathrm{L}, 10 \mathrm{~g} / \mathrm{L}$, and $15 \mathrm{~g} / \mathrm{L}$ under different experimental conditions.

As shown in Table 3, the adsorption percentage of chromium increased from 60.04 to $94.68 \%$ as the adsorbent dose increased from 1 to $15 \mathrm{~g} / \mathrm{L}$, whereas the uptake of $\mathrm{Cr}$ in $\mathrm{mg} / \mathrm{g}$ falls from $66.042 \mathrm{mg} / \mathrm{g}$ to $6.943 \mathrm{mg} / \mathrm{g}$ when the adsorbent dose increases from 1 to $15 \mathrm{~g} / \mathrm{L}$. Higher chromium adsorption percentage with the increase in the adsorbent dose can be attributed to increasing in surface area and the availability of more binding sites for adsorption (Karthik et al. 2018; Rao et al. 2002; Reddy et al. 2014; Umoren et al. 2013). The decrease in uptake of $\mathrm{Cr}$ in $\mathrm{mg} / \mathrm{g}$ with increased adsorbent

Table 3 Effect of adsorbent dose on $\mathrm{Cr}$ removal efficiency $\left(C_{\mathrm{o}}=110 \mathrm{mg} / \mathrm{L}\right.$, agitation speed $\left.=150 \mathrm{rpm}\right)$

\begin{tabular}{llllll}
\hline Dose $(\mathrm{g} / \mathrm{L})$ & $\mathrm{pH}$ & $\begin{array}{l}\text { Contact } \\
\text { time } \\
(\mathrm{min})\end{array}$ & $\mathrm{C}_{\mathrm{f}}(\mathrm{mg} / \mathrm{L})$ & $\begin{array}{l}\text { Cr adsorp- } \\
\text { tion } \%\end{array}$ & $q\left(\mathrm{mg} \mathrm{g}^{-1}\right)$ \\
\hline 1 & 3 & 180 & $43.958 \pm 0.072$ & 60.038 & 66.042 \\
5 & 3 & 180 & $14.667 \pm 0.036$ & 86.667 & 19.067 \\
10 & 3 & 180 & $9.063 \pm 0.063$ & 91.761 & 10.094 \\
15 & 3 & 180 & $5.854 \pm 0.130$ & 94.678 & 6.943 \\
\hline
\end{tabular}


dose may be due to the unchanged initial concentration of metal ion and the substantial adsorption capacity of the smallest adsorbent dose or less availability of surface area per unit weight (Ajmani et al. 2019a). Similar trends have also been reported by other authors relating to the effect of adsorbent doses on adsorption efficiency of $\mathrm{Cr}$ (Garg et al. 2007; Ghorbani et al. 2008).

\section{Effect of initial concentration of adsorbate}

The rate of adsorption is a function of the initial concentration of adsorbate, making it a substantial factor to be considered for the optimum experimental conditions of adsorption. The effect of the various initial concentrations of chromium $(30,50,70,90,110,130$, and $150 \mathrm{mg} / \mathrm{L})$ on $\mathrm{Cr}$ removal efficiency at constant experimental conditions like $\mathrm{pH} 3$, 180 -min contact time, $150 \mathrm{rpm}$ agitation speed and $15 \mathrm{~g} / \mathrm{L}$ adsorbent dose is presented in Table 4.

The adsorption percentage of chromium with the various initial concentrations of adsorbate in different constant experimental conditions such as $\mathrm{pH}$, contact time, agitation speed, and the adsorbent dose is presented in Table 4. According to the result exemplified in Table 4, the effect of initial concentration of $\mathrm{Cr}$ on the adsorption percentage shows a decreasing trend, which is $95.69,95.33,95.09$, $94.70,94.68,86.88$ and $83.94 \%$ with $30,50,70,90,110,130$ and $150 \mathrm{mg} / \mathrm{L}$ of adsorbate concentration, respectively. This can be explained by the fact that all adsorbents have a limited number of active sites, and at a specific concentration, the active sites become saturated (Banat et al. 2000; Tsai and Chen 2010). In another way, the reverse trend is observed in the case of $\mathrm{Cr}$ uptake in $\mathrm{mg} / \mathrm{g}$, which shows the increasing trend of Cr uptake, which is 1.91, 3.18, 4.44, 5.68, 6.94, 7.53 , and $8.39 \mathrm{mg} / \mathrm{g}$ with increasing initial concentration of adsorbate from 30 to $150 \mathrm{mg} / \mathrm{L}$ by $20 \mathrm{mg} / \mathrm{L}$ interval. This is maybe because, at constant adsorbent dose, the number of active sites to accommodate the chromium ions remains unchanged while with rising adsorbate concentrations, the chromium ions to be accommodated increased. Therefore, the loading was faster, with a higher initial concentration of adsorbate.

\section{Kinetic study for adsorption of chromium}

To understand the rate and type of adsorption that takes place, the study applies pseudo-first-order and pseudo-second-order kinetic models.

\section{Pseudo-first-order kinetic model}

The pseudo-first-order model is expressed by Eq. (3):

$\log \left(q_{\mathrm{e}}-q_{t}\right)=\log q_{e}-\frac{k_{1} t}{2.303}$

where $q_{\mathrm{e}}$ and $q_{t}\left(\mathrm{mgg}^{-1}\right)$ represent the amount of $\mathrm{Cr}$ ions adsorbed per unit weight of the adsorbents at equilibrium and time $\mathrm{t}(\mathrm{min})$, respectively, and $k_{1}$ is the rate constant of the pseudo-first-order kinetic model.

The pseudo-first-order kinetics is applicable if the plot of $\log \left(q_{\mathrm{e}}-q_{t}\right)$ against time $(t)$ shows a linear relationship. In addition, the straight-line plot of $\log \left(q_{\mathrm{e}}-q_{t}\right)$ versus $t$ was used to determine the rate constant $\left(k_{1}\right), q_{e}$ (cal) and the correlation coefficient $\left(R^{2}\right)$. The values of $k_{1}$ and $q_{\mathrm{e}}$ (cal) in $\mathrm{mg} / \mathrm{g}$ of $\mathrm{Cr}$ predicted from the plot shown in Fig. 4 are $4.836 \times$ $10^{-2}$ and $49.162 \mathrm{mg} / \mathrm{g}$, respectively. As the result presented in Table 5, the correlation coefficient $\left(R^{2}=0.5552\right)$ indicates that

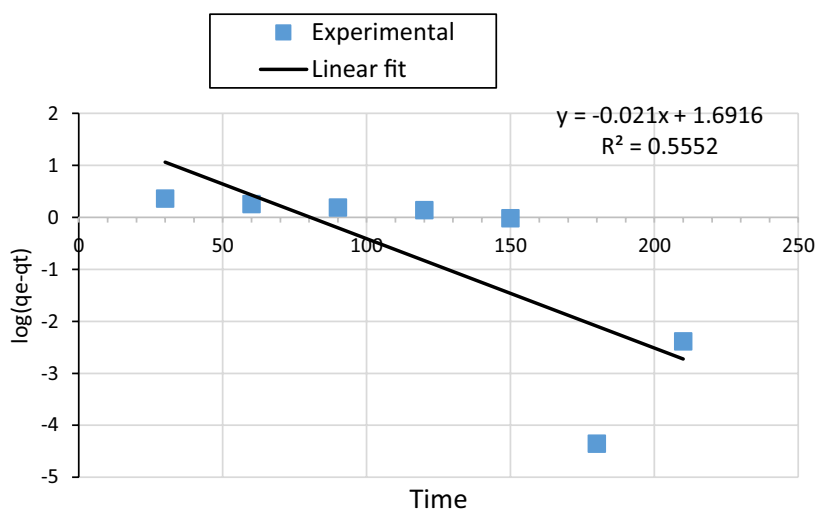

Fig. 4 Pseudo-first-order kinetics plots for the adsorption of $\mathrm{Cr}$ ions onto Odaracha adsorbent
Table 4 Effect of initial concentration of adsorbate on Cr removal efficiency

\begin{tabular}{llllllll}
\hline$C_{\mathrm{o}}(\mathrm{mg} / \mathrm{L})$ & $\begin{array}{l}\text { Agitation } \\
\text { speed }(\mathrm{rpm})\end{array}$ & $\begin{array}{l}\text { Contact } \\
\text { time }(\mathrm{min})\end{array}$ & Dose $(\mathrm{g} / \mathrm{L})$ & $\mathrm{pH}$ & $\mathrm{Av} C_{\mathrm{f}}(\mathrm{mg} / \mathrm{L})$ & $\mathrm{Cr}$ adsorption\% & $q\left(\mathrm{mg} \mathrm{g}^{-1}\right)$ \\
\hline 30 & 150 & 180 & 15 & 3 & $1.294 \pm 0.128$ & 95.688 & 1.914 \\
50 & 150 & 180 & 15 & 3 & $2.333 \pm 0.095$ & 95.333 & 3.178 \\
70 & 150 & 180 & 15 & 3 & $3.438 \pm 0.062$ & 95.089 & 4.438 \\
90 & 150 & 180 & 15 & 3 & $4.771 \pm 0.036$ & 94.699 & 5.682 \\
110 & 150 & 180 & 15 & 3 & $5.854 \pm 0.130$ & 94.678 & 6.943 \\
130 & 150 & 180 & 15 & 3 & $17.063 \pm 0.108$ & 86.875 & 7.529 \\
150 & 150 & 180 & 15 & 3 & $24.083 \pm 0.072$ & 83.944 & 8.394 \\
\hline
\end{tabular}


Table 5 Line-fit model of pseudo-first- and second-order kinetics for $\mathrm{Cr}$

\begin{tabular}{lllll}
\hline Adsorbent & Metal & First-order & & \\
\hline Odaracha & Chromium & $q_{e}(\exp ) \mathrm{mg} \mathrm{g}^{-1}$ & $q_{e}(\mathrm{cal}) \mathrm{mg} \mathrm{g}^{-1}$ & $k_{1}\left(\mathrm{~min}^{-1}\right)$ \\
& & 6.943 & 49.162 & $4.836 \times 10^{-2}$ \\
\hline Adsorbent & Metal & Second-order & & 0.5552 \\
\hline Odaracha & Chromium & $q_{e}(\exp ) \mathrm{mg} \mathrm{g}^{-1}$ & $q_{e}(\mathrm{cal}) \mathrm{mg} \mathrm{g}^{-1}$ & $k_{2}\left(\mathrm{~g} \mathrm{mg}^{-1} \mathrm{~min}^{-1}\right)$ \\
& & 6.943 & 7.7459 & $3.9989 \times 10^{-3}$ \\
\hline
\end{tabular}

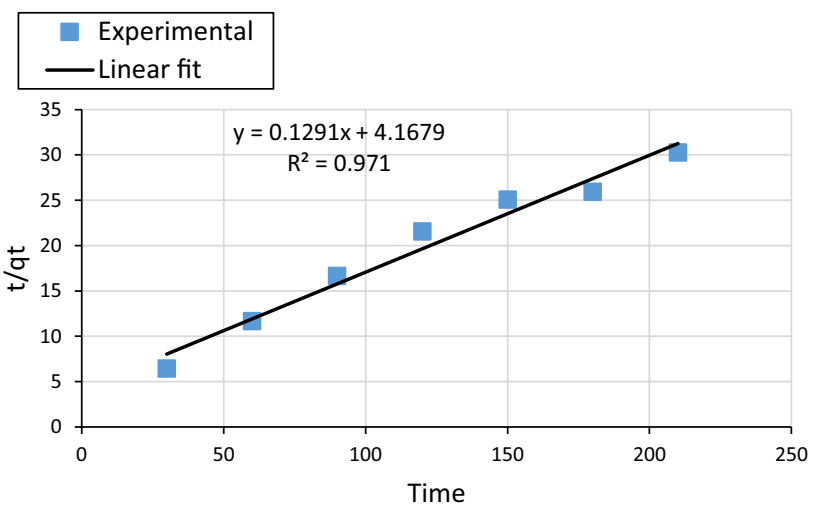

Fig. 5 Pseudo-second-order kinetics plots for the adsorption of $\mathrm{Cr}$ ions onto Odaracha adsorbent

the experimental data of the adsorption kinetics of chromium are not accurately supported by the pseudo-first-order model.

In a second way, the plot of $\log \left(q_{\mathrm{e}}-q_{t}\right)$ against time ( $\left.\mathrm{t}\right)$, which is shown in Fig. 4, does not display a linear relationship, which again communicates the unsuitability of the pseudofirst-order model. Furthermore, the experimental adsorption result $\left(q_{\mathrm{e}}(\mathrm{exp})\right)$ was not closer to $q_{\mathrm{e}}(\mathrm{cal})$. Therefore, the pseudo-first-order model is not suitable to explain the adsorption kinetics of $\mathrm{Cr}$ ions on Odaracha adsorbent (Arshadi et al. 2014; Sag and Aktay 2002).

\section{Pseudo-second-order kinetic model}

The pseudo-second-order model is expressed by Eq. (4):

$\frac{t}{q_{t}}=\frac{1}{K_{2} q_{e}{ }^{2}}+\frac{t}{q_{e}}$

where $q_{e}$ and $q_{t}\left(\mathrm{mg} \mathrm{g}^{-1}\right)$ represent the amount of $\mathrm{Cr}$ ions adsorbed per unit weight of the adsorbents at equilibrium and time $t(\mathrm{~min})$, respectively, and $k_{2}$ is the rate constant of the pseudo-second-order kinetic model. The rate constant $\left(k_{2}\right)$ and calculated equilibrium adsorption capacity $\left(q_{\mathrm{e}}(\mathrm{cal})\right)$ can be determined from the slope and intercept of the plot $t / q_{t}$ versus $t$, which is shown in Fig. 5. The plot $t / q_{t}$ versus $t$ should give a straight line to apply the pseudo-second-order kinetic model. The plot of $t / q_{t}$ versus $t$ for pseudo-secondorder yields a good straight line with the highest correlation coefficient result approaching $1\left(R^{2}=0.971\right)$. In addition, as presented in Table 5, the experimental adsorption equilibrium value $\left(q_{\mathrm{e}}\right.$ (exp.) $\left.=6.943 \mathrm{mg} \mathrm{g}^{-1}\right)$ was well matched with the calculated adsorption equilibrium value $\left(q_{\mathrm{e}}(\mathrm{cal})=.7.745 \mathrm{mg} \mathrm{g}^{-1}\right)$. Therefore, the experimental data of the adsorption kinetics of chromium are accurately supported by a pseudo-second-order model. Thus, this finding suggests that the rate-limiting factor in the adsorption of chromium by Odaracha adsorbent is chemisorption involving the exchange of $\mathrm{Cr}$ ions with functional groups in the adsorbent (Rahman and Sathasivam 2015; Senthil and Gayothri, 2013).

\section{Isotherm model for adsorption of chromium}

In this study, the evaluation of the equilibrium of the adsorption process was carried out by introducing the experimental results into Langmuir and Freundlich isotherm models.

\section{Langmuir adsorption isotherm model for chromium}

Equilibrium study for the removal of chromium was performed on the Odaracha adsorbent powder by Langmuir adsorption model. According to the Langmuir isotherm model, the adsorption sites are uniformly equal and no attraction occurs between the adsorbed molecules; hence, monolayers of the molecules are deposited on the Odaracha powder (Langmuir 1916).

The linearized form of this model is presented in Eq. (5) and was used in the determination of its parameters in accordance with Fig. 6.

$\frac{1}{q_{\mathrm{e}}}=\frac{1}{q_{\mathrm{m}}}+\frac{1}{q_{\mathrm{m}} K_{\mathrm{L}}} \cdot \frac{1}{C_{\mathrm{e}}}$

where $q_{\mathrm{e}}$ represents the amount of adsorbed $\mathrm{Cr}$ in $\mathrm{mg} / \mathrm{g}$ of the adsorbent, and $C_{\mathrm{e}}$ is the concentration of $\mathrm{Cr}$ at equilibrium in $\mathrm{mg} / \mathrm{L} . K_{\mathrm{L}}$ and $q_{\mathrm{m}}$ represent Langmuir adsorption 


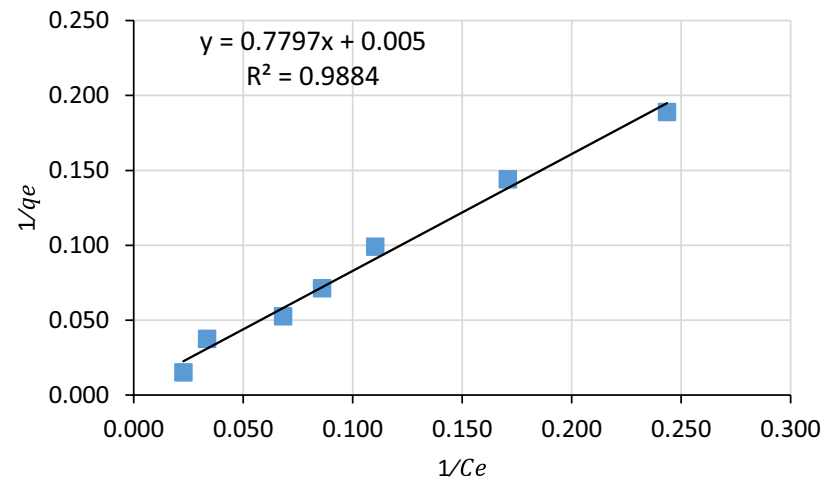

Fig. 6 Langmuir adsorption isotherm model for chromium

constant and the maximum amount of adsorbate that can be adsorbed on Odaracha adsorbent (Langmuir 1918). The values of $K_{\mathrm{L}}$ and $q_{\mathrm{m}}$ for this study were determined from the slope and intercept shown in Fig. 6. One of the essential features of this model is its ability to determine $R_{\mathrm{L}}$ as shown in Eq. (6), which is a dimensionless parameter known as equilibrium parameter or separation factor (Webber and Chakravarti 1974).

$R_{\mathrm{L}}=\frac{1}{1+\left(1+K_{\mathrm{L}}+C_{\mathrm{o}}\right)}$

The adsorption process can be described as unfavorable if $R_{\mathrm{L}}>1$, linear if $R_{\mathrm{L}}=1$, favorable if $0<R_{\mathrm{L}}<1$ and irreversible if $R_{\mathrm{L}}=0$. The value of $R_{\mathrm{L}}$ obtained in this study as presented in Table 6 is between 0 and 1, which suggests the Langmuir isotherm model is favorable in this study. The maximum monolayer coverage capacity $\left(q_{\mathrm{m}}\right)$ obtained was $200 \mathrm{mg} \mathrm{g}^{-1}$. This result indicates that the maximum adsorption potential of $1 \mathrm{~g}$ of Odaracha adsorbent.

\section{Freundlich adsorption isotherm model for $\mathrm{Cr}$}

The Freundlich isotherm model is an empirical equation employed to describe heterogeneous systems. In this model, it is described that during the adsorption process different sites of the adsorbent are involved with several adsorption energy (Kumar and Kirthika 2009). The linearized form of the Freundlich isotherm model is shown in Eq. (7).

$\log q_{\mathrm{e}}=\log K_{f}+(1 / n) \log C_{\mathrm{e}}$

where $q_{\mathrm{e}}$ is the metal uptake $\left(\mathrm{mg} \mathrm{g}^{-1}\right)$ at equilibrium, $K_{f}$ is the measure of the adsorption capacity, $1 / n$ is the adsorption intensity, and $C_{\mathrm{e}}$ is the final concentration of $\mathrm{Cr}$ in solution, or equilibrium concentration $\left(\mathrm{mg} \mathrm{L}^{-1}\right)$. The Freundlich isotherm constants $K_{f}$ and $1 / n$ are evaluated from the intercept and the slope, respectively, of the linear plot of $\log q_{\mathrm{e}}$ versus $\log C_{\mathrm{e}}$ shown in Fig. 7.

If $\mathrm{n}$ is between 1 and 10, it indicates favorable adsorption (Goldberg 2005). However, if $1 / n$ is $<1$ it indicates normal adsorption, but if it is $>1$, it implies cooperative adsorption (Mohan and Karthikeyan 1997). The numerical value of $1 / n$ presented in Table 6 is 0.998 , indicating a favorable adsorption process (Kannan et al. 2013).

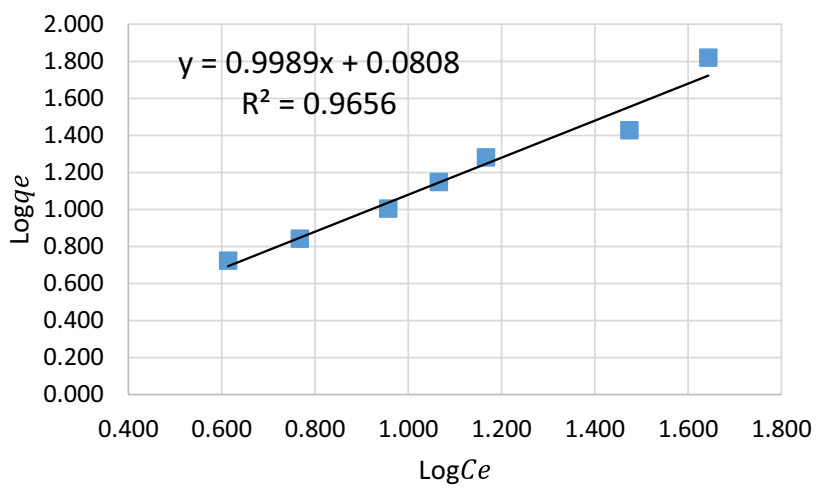

Fig. 7 Freundlich adsorption isotherm model for chromium

Table 6 Langmuir and Freundlich isotherm model constants for adsorption of $\mathrm{Cr}$

\begin{tabular}{lllll}
\hline Adsorbent & Metal & Langmuir & & \\
\hline Odaracha & Chromium & $q_{m} \mathrm{mg} \mathrm{g}^{-1}$ & $K_{\mathrm{L}}$ & $R_{L}$ \\
& & 200 & 0.0064 & $R^{2}$ \\
& Metal & Freundlich & & 0.9884 \\
\hline Adsorbent & Chromium & $K_{f}$ & $1 / n$ & $R^{2}$ \\
\hline Odaracha & & 1.2045 & 0.998 & 0.9656 \\
& & & \\
\hline
\end{tabular}


Table 7 Comparison between the adsorption capacities of various natural adsorbents and Odaracha soil

\begin{tabular}{lll}
\hline Type of adsorbents & $\begin{array}{l}\text { Adsorption } \\
\text { capacity } q_{\mathrm{m}} \\
(\mathrm{mg} / \mathrm{g})\end{array}$ & References \\
\hline Brazilian smectite & 97.23 & Guerra et al. (2010) \\
Rosehip seed shell & 15.17 & Şerife and Erol (2019) \\
Modified vermiculite & 87.72 & Liu et al. (2011) \\
Bentonite & 48.83 & Wanees et al. (2012) \\
Ziziphus jujuba cores & 196.38 & Labied et al. (2018) \\
Natural sepiolite & 37 & Marjanovic et al. (2013) \\
Odaracha soil & 200 & This study \\
\hline
\end{tabular}

\section{Comparison of Odaracha and other natural adsorbents}

A comparison results between the maximum adsorption capacity of $\mathrm{Cr}$ ions onto Odaracha adsorbent and other adsorbents are presented in Table 7. Table 7 shows that the maximum adsorption capacity obtained in this study was higher than other natural adsorbents illustrated in Table 7. Therefore, Odaracha soil can be used as effective and an alternative low-cost adsorbent for chromium.

\section{Conclusions}

In the exploration result of this study, Odaracha soil sourced from Saketa district of Ethiopia was used for the removal of chromium from synthetic wastewater. The characterization results of Fourier transform infrared, X-ray powder diffraction analysis, and the surface morphology of Odaracha adsorbent, which shows the pores of the surface of the adsorbent before and after adsorption, were an indicator for its adsorption capacity. The adsorption capacity of Odaracha adsorbent was influenced by a number of factors such as contact time, $\mathrm{pH}$, adsorbent dosage, and initial concentration of adsorbate. The optimum range of contact time, $\mathrm{pH}$, Odaracha dose, and initial concentration of chromium obtained by the batch experiment was $180 \mathrm{~min}, \mathrm{pH} \mathrm{3,15} \mathrm{g} / \mathrm{L}$, and $30 \mathrm{mg} / \mathrm{L}$, respectively. With optimum experimental conditions and at room temperature, Odaracha adsorbent removed $94.68 \% \mathrm{Cr}$ from the wastewater. The adsorption kinetics of chromium is accurately supported with a pseudo-secondorder model. The isotherm data were analyzed by Langmuir and Freundlich isotherms. The maximum monolayer coverage adsorption capacity from the Langmuir adsorption isotherm model was $200 \mathrm{mg} \mathrm{g}^{-1}$. Generally, the ability of Odaracha adsorbent in removing $\mathrm{Cr}$ from aqueous solutions has the potential to solve the problem of chromium-containing industrial effluents, which continue to pose increasing risks to human health and environment.
Acknowledgements The authors would like to acknowledge both Addis Ababa University, Center of Environmental Science and Jigjiga University for their holistic support including financial aid.

Author contributions YB contributed to experimental design, conducting experiments, analyzed and interpreted the data, and wrote the manuscript. SL contributed to the experimental design, supervising the whole research work, and editing the manuscript. GA involved in the characterization of the adsorbent material and editing the manuscript.

Funding This research was financially supported by Addis Ababa University and Jigjiga University.

Data Availability The authors declare that the data supporting the findings of this study are available within the article, and other supplementary data are available from the corresponding author upon request.

\section{Compliance with ethical standards}

Conflict of interest The authors declare that they have no conflict of interests.

Ethical approval Not applicable.

Consent for publication Not applicable.

Open Access This article is licensed under a Creative Commons Attribution 4.0 International License, which permits use, sharing, adaptation, distribution and reproduction in any medium or format, as long as you give appropriate credit to the original author(s) and the source, provide a link to the Creative Commons licence, and indicate if changes were made. The images or other third party material in this article are included in the article's Creative Commons licence, unless indicated otherwise in a credit line to the material. If material is not included in the article's Creative Commons licence and your intended use is not permitted by statutory regulation or exceeds the permitted use, you will need to obtain permission directly from the copyright holder. To view a copy of this licence, visit http://creativecommons.org/licenses/by/4.0/.

\section{References}

Ajmani A, Shahnaz T, Narayanan S, Narayanasamy S (2019a) Equilibrium, kinetics and thermodynamics of hexavalent chromium biosorption on pristine and zinc chloride activated Senna siamea seed pods. Chem Ecol 35(4):379-396. https://doi. org/10.1080/02757540.2019.1584614

Ajmani A, Shahnaz T, Subbiah S, Narayanasamy S (2019b) Hexavalent chromium adsorption on virgin, biochar, and chemically modified carbons prepared from Phanera vahlii fruit biomass: equilibrium, kinetics, and thermodynamics approach. Environ Sci Pollut Res 26:32137-32150

Arshadi M, Amiri M, Mousavi S (2014) Kinetic, equilibrium and thermodynamic investigations of $\mathrm{Ni}(\mathrm{II}), \mathrm{Cd}(\mathrm{II}), \mathrm{Cu}(\mathrm{II})$ and $\mathrm{Co}(\mathrm{II})$ adsorption on barley straw ash. Water Resour Ind 6:1-17

Attia A, Khedr S, Elkholy S (2010) Adsorption of chromium ion (VI) by acid activated carbon. Braz J Chem Eng 27(1):183-193

Banat FA, Al-Bashir B, Al-Asheh S, Hayajneh O (2000) Adsorption of phenol by bentonite. Environ Pollut 107:391-398

Costanzo F, Silvestrell PL, Ancilotto F (2012) Physisorption, diffusion and chemisorbed pathways of $\mathrm{H} 2$ molecule on Graphene and 
single walled nanotube by first principle calculations. J Chem Theory Comput 8(4):1288-1294

Dagmawi M, Mekibib D (2013) Chromium removal from modjo tannery wastewater using moringa stenopetala seed powder as an adsorbent. Water, Air, \& Soil Pollut 224(12):1-10

Eliku T, Leta S (2018) Spatial and seasonal variation in physicochemical parameters and heavy metals in Awash River, Ethiopia. Appl Water Sci 8:177. https://doi.org/10.1007/s13201-018-0803-x

Garg UK, Kaur MP, Garg VK, Sud D (2007) Removal of hexavalent chromium from aqueous solution by agricultural waste biomass. Hazard Mater 140:60-68

Ghoneim M, El-Desoky H, El-Moselhy K, Amer A, ElNaga E, Mohamedein L, Al-Prol A (2014) Removal of cadmium from aqueous solution using marie green algae, Ulvalactuca Egypt. J Aquat Res 40:235-242

Ghorbani F, Younesi H, Ghasempouri SM, Zinatizadeh AA, Amini M, Daneshi A (2008) Application of response surface methodology for optimization of cadmium biosorption in an aqueous solution by Saccharomyces cerevisiae. Chem Eng J 145(2):267-275

Goldberg S (2005) Equations and models describing adsorption processes in soils. SSSA Book, Soil Science Society of American, USA

Guerra DL, Oliveira HC, da Costa CP, Viana RR, Airoldi C (2010) Adsorption of chromium (VI) ions on Brazilian smectite: effect of contact time, $\mathrm{pH}$, concentration, and calorimetric investigation. CATENA 82:35-44

Gulipalli CS, Prasad B, Wasewar KL (2011) Batch study, equilibirum and kinetics of adsorption of selenium using rice husk ash (RHA). J Eng Sci Technol 6:586-605

Hoidy W, Ahmed B, Ibrahim N (2009) Synthesis and characterization of organo clay from soidium montmorrillionite and fatty hydroxamic acids. J Appl Sci 6(8):167-172

Hsua NH, Wanga YH, Liaoa HST, Tzoua YM, Huanga YM (2009) Removal of hexavalent chromium from acidic aqueous solutions using rice straw-derived carbon. J Hazard Mater 171:1066-1070

Jiang W, Pelaez M, Dionysiou DD, Entezari MH, Tsoutsou D, O'Shea K (2013) Chromium (VI) removal by maghemite nanoparticles. Chem Eng J 222:527-533

Kannan C, Muthuraja K, Devi M (2013) Hazardous dyes removal from aqueous solution over mesoporous aluminophosphate with textural porosity by adsorption. J Hazard Mater 244(245):10-20

Karthik V, Saravanan K, Patra C, Ushadevi B, Vairam S, Selvaraju N (2018) Biosorption of Acid Yellow 12 from simulated wastewater by non-viable $\mathrm{T}$. harzianum: kinetics, isotherm and thermodynamic studies. Int J Environ Sci Technol. https://doi.org/10.1007/ s13762-018-2073-4

Kumar PS, Kirthika K (2009) Equilibrium and kinetic study of adsorption of nickel from aqueous solution onto bael tree leaf powder. J Eng Sci Technol 4(4):351-363

Kyziol-Komosinska J, Rosik-Dulewska C, Dzieniszewska A, Pająk M, Krzyzewska I (2014) Removal of Cr (III) ions from water and wastewater by sorption onto peats clays occurring in an overburden of lignite beds in Central Poland. Environ Protect Eng 40(1):5-22. https://doi.org/10.5277/epe140101

Labied R, Benturki O, Hamitouche AE, Donnot A (2018) Adsorption of hexavalent chromium by activated carbon obtained from a waste lignocellulosic material (Ziziphus jujuba cores): kinetic, equilibrium, and thermodynamic study. Adsorp Sci Technol 36(3-4):1066-1099. https://doi.org/10.1177/0263617417750739

Langmuir I (1916) The construction and fundamental properties of solids and liquids. Part I. Solids J Am Chem Soc 38:2221-2295

Langmuir I (1918) The adsorption of gases on plane surfaces of glass, mica and platinum. J Am Chem Soc 40:1361-1403

Liu Y, Li H, Tan GQ, Zhu XH (2011) Fe2+ modified vermiculite for the removal of chromium (VI) from aqueous solution. Sep Sci Technol 46:290-299
Malek NANN (2007) Surfactant modified zeolite Y as a sorbent for some chromium and arsenic species in water. Universiti Teknologi Malaysia

Marjanovic V, Lazarevic S, Jankovic-Castvan I, Jokic B, Janackovic DJ, Petrovic R (2013) Adsorption of chromium (VI) from aqueous solutions onto amine functionalized natural and acid-activated sepiolites. Appl Clay Sci 80-81:202-210

Mohan S, Karthikeyan J (1997) Removal of lignin and tannin color from aqueous solution by adsorption onto activated charcoal. Environ Pollut 97:183-187

Ofudje E, Awotula A, Oladipo G, Williams O (2014) Detoxification of chromium (VI) ions in aqueous solution via adsorption by raw and activated Carbon prepared from sugarcane bio waste. Covenant $\mathrm{J}$ Phys Life Sci 2:110-122

Owlad M, Aroua MK, Daud WM (2010) Hexavalent chromium adsorption on impregnated palm shell activated carbon with polyethyleneimine. Bioresour Technol 101:5098-5103. https://doi. org/10.1016/j.biortech.2010.01.135

Pranay AR, Anup C, Yogesh M (2015) Various techniques for the removal of Chromium and lead from waste water: review. Int J Emerg Trends Eng Basic Sci (IJEEBS) 2(2):64-67

Rahman MS, Sathasivam KV (2015) Heavy metal adsorption onto Kappaphycus sp. from aqueous solutions: the use of error functions for validation of isotherm and kinetics models. Hindawi Publishing Corporation, BioMed Research International 1-13.

Rangabhashiyam S, Selvaraju N (2015) Adsorptive remediation of hexavalent chromium from synthetic wastewater by a natural and ZnCl2 activated Sterculia guttata shell. J Mol Liq 207:39-49

Rao M, Parwate AV, Bhole AG (2002) Removal of Cr6+ and Ni2+ from aqueous solution using bagasse and fly ash. Waste Manag 22:821-830

Reddy NA, Lakshmipathy R, Sarada NC (2014) Application of Citrullus lanatus rind as biosorbent for removal of trivalent chromium from aqueous solution. Alexandria Eng J 53(4):969-975

Sag Y, Aktay F (2002) Kinetic studies on sorption of Cr (VI) and $\mathrm{Cu}$ (II) ions by chitin, chitosan and Rhizopus arrhizus. Biochem Eng J 1(12):143-153

Senthil K, Gayothri J (2013) Adsorption of Pb2+ ions from aqueous solutions onto bael tree leaf powder: isotherms, kinetics and thermodynamics study. J Chem Eng Sci Technol 4(4):381-399

Şerife P, Erol P (2019) Comparative study of Cr(VI) removal by bio-waste adsorbents: equilibrium, kinetics, and thermodynamic. J Anal Sci Technol 10:15. https://doi.org/10.1186/s4054 3-019-0175-3

Shahnaz T, Mohamed Madhar Fazil S, Padmanaban VC, Narayanasamy S (2020a) Surface modification of nanocellulose using polypyrrole for the adsorptive removal of Congo red dye and chromium in binary mixture. Int J Biol Macromol 151:322-332

Shahnaz T, Sharma V, Subbiah S, Narayanasamy S (2020b) Multivariate optimisation of $\mathrm{Cr}$ (VI), $\mathrm{Co}$ (III) and $\mathrm{Cu}$ (II) adsorption onto nanobentonite incorporated nanocellulose/chitosan aerogel using response surface methodology. J Water Process Eng 36:101283

Singha B, Das SK (2011) Biosorption of Cr (VI) ions from aqueous solutions: kinetics, equilibrium, thermodynamics and desorption studies. Colloids Surf, B 84:221-232

Tsai WT, Chen HR (2010) Removal of malachite green from aqueous solution using low-cost chlorella-based biomass. J Hazard Mater 175(1):844-849

Umoren SA, Etim UJ, Israel AU (2013) Adsorption of methylene blue from industrial effluent using poly(vinyl alcohol). J Mater Environ Sci 4:75-86

Wanees SA, Ahmed AM, Adam MS, Mohamed MW (2012) Adsorption studies on the removal of hexavalent chromium-contaminated wastewater using activated carbon and bentonite. Chem $\mathrm{J}$ 2:95-105 
Webber TN, Chakravarti RK (1974) Pore and solid diffusion models for fixed bed adsorbers. AlChe J 20:228-238

Zhu X, Han B (2013) Adsorption behavior of chromium (VI) on the HDTMA-modified- zeolite. J Food Agric Environ 11(3):2488-2492
Publisher's Note Springer Nature remains neutral with regard to jurisdictional claims in published maps and institutional affiliations. 